Original scientific article

$$
\text { УДК 911.3:33(4-11)(4-191.2) }
$$

\title{
INDUSTRIAL ACTIVITY IN CEE COUNTRIES: POST-CRISIS TRANSFORMATION OF SPATIAL AND FUNCTIONAL STRUCTURE
}

\author{
Mikhail M. Lobanov*1 \\ * Institute of Economics, Russian Academy of Sciences
}

Извод: Овај рад је посвећен проблемима промене индустријске структуре на примеру земаља Централне и Источне Европе. Континуирана еволуција просторне и функционалне структуре индустријске активности се разматра на нивоу територијално-производних формација. Разлика у спољним и унутрашњим условима њиховог развоја (на пример, пре и после глобалне кризе) је требало да утиче на водеће механизме индустријског комплексирања - од моделирања до самоорганизовања. Проблем размештаја индустријских објеката мора се анализирати с обзиром на савремене интеграционе трендове који утичу на прекограничну сарадњу. Осим тога, резултати нашег истраживања су везани за одређивање могућих структурних промена и перспективу територијално-производних формација у Централној и Источној Европи у периоду после кризе. Ови налази су засновани не само на анализи података, већ и на примени методологије мапирања.

Кључне речи: индустрија, структурна трансформација, индустријско комплексирање, индустријски кластер, Централна и Источна Европа.

\begin{abstract}
Given paper deals with the problem of industry structure shifts on the example of CEE countries. The continuous evolution of spatial and functional structure of industrial activity is considered on the level of territorial-production formations. The difference in the external and internal conditions of their development (e.g. before and after global crisis effects spread) is supposed to influence the driving mechanisms of industrial complexation from modelling to self-organisation. The problem of industrial facilities placement should be also addressed with due regard for contemporary integration trends influencing the scale of cross-border cooperation. Besides that, our investigation is resulted in the determination of the possible structural changes and prospects of the territorial-production formations in $\mathrm{CEE}$ in the post-crisis period. These findings are based not only on data analysis but the application of mapping methodology developed in the paper.
\end{abstract}

Key words: industry, structural transformation, industrial complexation, industrial cluster, Central and Eastern Europe.

Date submitted: 26 October 2014; Date accepted: 13 December 2014

\footnotetext{
${ }^{1}$ Correspondence to: m.m.lobanov@rambler.ru
} 


\section{Formation of spatial and functional structure of industry: main features and tendencies}

\section{Industrial development under the conditions of globalization trends diffusion}

World economy organisation trends have a multi-scale impact on the formation of production systems, which can be described by numerous case studies. Most of the investigations are based on a post-industrial approach to the organisation of productive forces. We argue that post-industrialism remains a pattern of behaviour for some economies and is presented only in a limited number of market niches that are characterised by creative and innovative management. The most constructive criticism of the post-industrial society concept is reflected by various geographic schools (e.g., A.J. Scott, E. Soja, and M. Storper) that take into account the spatial factors in the development of the economic systems (Scott \& Storper, 2009). These researchers point to the primary role of industry in shaping the parameters of the services development and even argue about the gradual transformation of the functioning principles in the tertiary sector under the influence of industrialisation.

The formation of a post-industrial economy based on knowledge is a key condition of the development of the information society (Audretsch, 1997; Coe, et al., 2004; Iammarino \& McCann, 2006). It is assumed that, due to enhanced information channels, the role of information in the global economic evolution will become decisive. However, it is obvious that these trends will not only lead to widely declared goods but also to latent threats. Features of information, such as reduplication and progressive accumulation, can lead to a loss of control over information processing, which will result in systematic instability and uncertainty (a bifurcation point). In addition, the acceleration of the level of data exchange and the development of information channels should provide 'homo informaticus' - the skills to manage the processes of exponential growth (in various manifestations of Moore's law in society and economy). The widespread belief that, in the near future, the access to information will become a key factor of placement is debatable. On the contrary, the widespread development of channels of information exchange and the creation of equal conditions for access to them, in effect, encourage a return to traditional principles of competitiveness and to the preservation of the established factor system. The removing of barriers of information spread, for instance, can be illustrated by the development of the Internet. In other words, in the post-industrial society, characterised by continuous information space, the differentiation in terms of access to information will be leveled. 
Increased transparency of a global economy influences the extent of diffusion of economic and socio-political institutions that, in fact, tend to reflect the value systems of managerial elites of the world's leading powers. In particular, these processes can be observed in CEE and SEE countries. Property reform (private sector development, privatisation of public assets), as well as the formation of a competitive business environment due to freepricing and market de-monopolisation, play an important role in the transformation of the industrial structure of post-socialist countries. The active involvement of long-term capital enhances the competitiveness of national economies and individual industries and helps to solve the problems of territorial imbalances and employment. The efficient functioning of a large number of industrial enterprises depends on their degree of openness to cross-border trade and financial flows. Companies oriented to foreign markets encourage foreign trade, but these conditions also lead to a dangerous dependency on the decisions of a limited number of market leaders. Other examples of the negative impact of integration on the development of national markets include the effect of economic dualism, the loss of sovereignty in determining the priorities of an industrial policy (e.g., the delegation of these functions to regulatory and supervisory authorities of integration groupings) and the reduction of the overall level of protectionism that places some industries of traditional specialisation on the brink of survival.

Global and regional crises have different effects on the structural transformation of industry. The change in market conditions is accompanied by the appearance of potentials for restructuring and improving the efficiency of production systems. Diffusion, as a result of crisis, in a globalizing world transforms a combination of mechanisms in industrial systems and detects imbalances and hidden pressure points in their development. For example, the tendency of transfer among production facilities creates countries that are characterised by comparative competitive advantages during and after recession periods. The leading recipients of foreign investments cease to be the final and, rather, become the intermediate link in international production externalisation, thus producing a transmission country. These processes also exist in the context of macroeconomic stability as the crises contribute to the acceleration of their development.

\section{Principles of organisation and functioning mechanisms in industry}

We offer a differentiated concept of the principles of organisation and functioning mechanisms. The principles should be classified as timeless/changeless patterns of spatial organisation of economic entities and should not be dependent on economic-cultural background or on political and ideological doctrines. These principles include: 
- an interest in maximising profits in the market economy and in minimising costs in administratively planned economies (if the prices are assumed constant);

- the relative advantages of spatial concentration of production units (Weber's agglomeration effect);

- the ability of primary industrial facilities to self-organise and their involvement in value-added accumulation chains (construction or self-organised technological cycles).

The self-organisation of production and non-production facilities or units that seek the most effective interaction contributes (indirectly) to the rationalisation of the economic structure. Rationalisation involves the principles of organisation of productive activities, but each stage of development of a global, regional or national industry corresponds to some combination of mechanisms designed to achieve the priorities of economic development. Functioning mechanisms can and should be differentiated by sector while the principles of the organisation characterise industrial production chains as a whole. In this regard, outsourcing and subcontracting, for example, are not principles but, rather, present-day mechanisms for a solution to structural rationalisation problems within certain industries. The rotation of such mechanisms is expected for the evolution of the global economy. For example, in the 1970s and 1980s, one can single out the importance of specialisation and combination while the 1950 s and 1960 s were characterised by universal tendencies of production theory and practice.

\section{Shortcomings of cluster theory and cluster policy}

Investigations and studies of industrial systems usually consider various forms of agglomeration effects and their influence on the configuration of production complexes. Industrial agglomeration does help to reduce the level of variable costs, but its contribution to the efficiency of the enterprises of the complex becomes less significant, especially in the expansion of non-material flows between entities that do not depend on the degree of geographic proximity. The theory of industrial and regional clusters is one of the most debated doctrines concerning production location. In our previous works, we have identified and described more than a dozen shortcomings and stereotypes, along with a practical background, of the cluster theory (Lobanov, 2011a).

Among the shortcomings, we note:

- multiple interpretations of the basic concepts of the theory;

- confusion between the properties of functional and spatial systems;

- the hybridisation of functional and spatial properties;

- the absence of a definite hierarchy and the subordination of cluster formations; 
- the indoctrination of the industrial cluster policy;

- the production of innovative goods and services as a condition for cluster formation;

- the underestimation of the role of traditional industries and enterprises in the process of cluster formation;

- the low representation of cluster mapping results (see below).

- The wide-spread beliefs and stereotypes of the cluster theory include

- the limited influence of the state on the formation and operation of clusters;

- the existence of a unified cluster policy;

- the exchange of voluntary information (know-how, technology) in clusters;

- the interest of cooperating firms in a competitive environment;

- the identity of properties of urban agglomerations and agglomeration effects of industrial organisation.

Here, we describe the shortcomings of cluster mapping methodology to identify potential conditions for clusters formation developed by the experts of Harvard Business School. This methodology is based on a comparison of indicators of geographic concentration and production specialisation. The proposal to use results of cluster mapping in industrial policy programs has received support only in the U.S. while the corresponding calculations for EU countries have, thus far, only scientific, not practical, significance ${ }^{2}$.

Cluster mapping methodology is based solely on employment data; thus, the results of the calculations are influenced by a labour-intensity factor. For example, high-tech companies with high labour productivity do not have significant weight to form clusters in the structure of employment In addition, cluster mapping does not allow for the identification of boundaries or spatial parameters of potential clusters for several reasons. First, most calculations (by European Cluster Observatory and others) use territorial-administrative units, NUTS 2

2 Comparison of European and American clusters, according to their industrial specialisation, is quite difficult due to the use of different classifications of economic activities (NACE, SIC). To identify potential clusters in the new EU member states, C. Ketels and O. Sölvell operated the data collected by statistical regions NUTS 2 and took into account three indicators: the absolute number of employed in given sector in the region ( $\geq 15$ thous.), the coefficient of specialization $(\geq 1,75$, by employment) and the share of industry in the region-wide structure of employment $(\geq 7 \%)$. It was assumed that a regional cluster has a competitive advantage if it gets into the top $10 \%$ of the EU clusters by the above- mentioned parameters. It should be noted that the method of calculating the specialization / localization index varies depending on the parameters of study (Florence-Winsley coefficient, revealed comparative advantage (RCA) by B. Balassa, among others) (Sölvell, Lindqvist \& Ketels, 2003). 
or even NUTS 1 , that are too large ${ }^{3}$. Recommendations based on these generalised statistics, therefore, do not bear any practical use; however, in some cases, there are no alternatives. Data from units of lower order (NUTS 3) are often fragmented or in a closed access. Second, the studied statistical regions do not coincide with the administrative grid adopted in the EU countries, and the majority of them do not reflect the specifics of spatial socio-economic differentiation. The use of administrative-territorial units for the study of economic phenomena and processes leads to spurious conclusions. In particular, it nullifies the possibility of determining a cross-border cluster configuration. To get closer to the elimination of this contradiction and to ground the analysis of statistical data by economic zoning units, we need to actualise approaches developed by the Soviet Regional School of Economic Geography ${ }^{4}$.

\section{Industrial complexation in market conditions}

Our approach, in contrast to the traditional cluster paradigm, is based on the assumption of production complexing / complexation development. The combination of territorial-production complex internal connections occurs irrespective of the conditions of its formation, that is, whether it is as a result of the state modelling or the process of business entities self-organising under the influence of market forces. Leading vertical linkages of the complex can equally be implemented within a single legal institution (e.g., vertically integrated corporations) or by the operation of a large number of legally independent companies. Moreover, the intensity of vertical linkages does not suppress complex networks; rather, on the contrary, it stimulates the action of horizontal linkages, which are involved in the creation of independent territorial-production formations on different levels. Thus, we propose to refer to existing specialised single-industry agglomerations (which are considered, in the foreign studies, as spatial clusters) as a territorial-production formation of cluster type.

Spatial clusters of different specialisation are characterised by their functional autonomy, which indirectly highlights the potentially low degree

\footnotetext{
${ }^{3}$ NUTS (Nomenclature of Territorial Units for Statistics) is a standard developed by the European Union.

${ }^{4}$ One of the most successful attempts to complement and enhance the method of cluster mapping undertaken by an international research group that studied the process of clustering in Hungary by NUTS 3 regions (M. Szanyi, P. Czimadia, I. Iwasaki and others). They took into account not only employment information but also the size of the companies and data on value-added and accumulated investments. In addition, they calculated the Gini index to determine the features of the cluster member organization (level of companies differentiated by size) (Szanyi, Csizmadia and Iwasaki, 2010).
} 
of connectivity of territorial structure elements in the case of cluster policy implementation. The solution is the incorporation of internal horizontal linkages of cluster formations in a more compound system of multi-level relationships in a territorial-production complex.

In such complexes, different levels of the value-added increment are usually represented by a set of concentrated and horizontally integrated enterprises operating in a competitive environment with elements of cooperation.

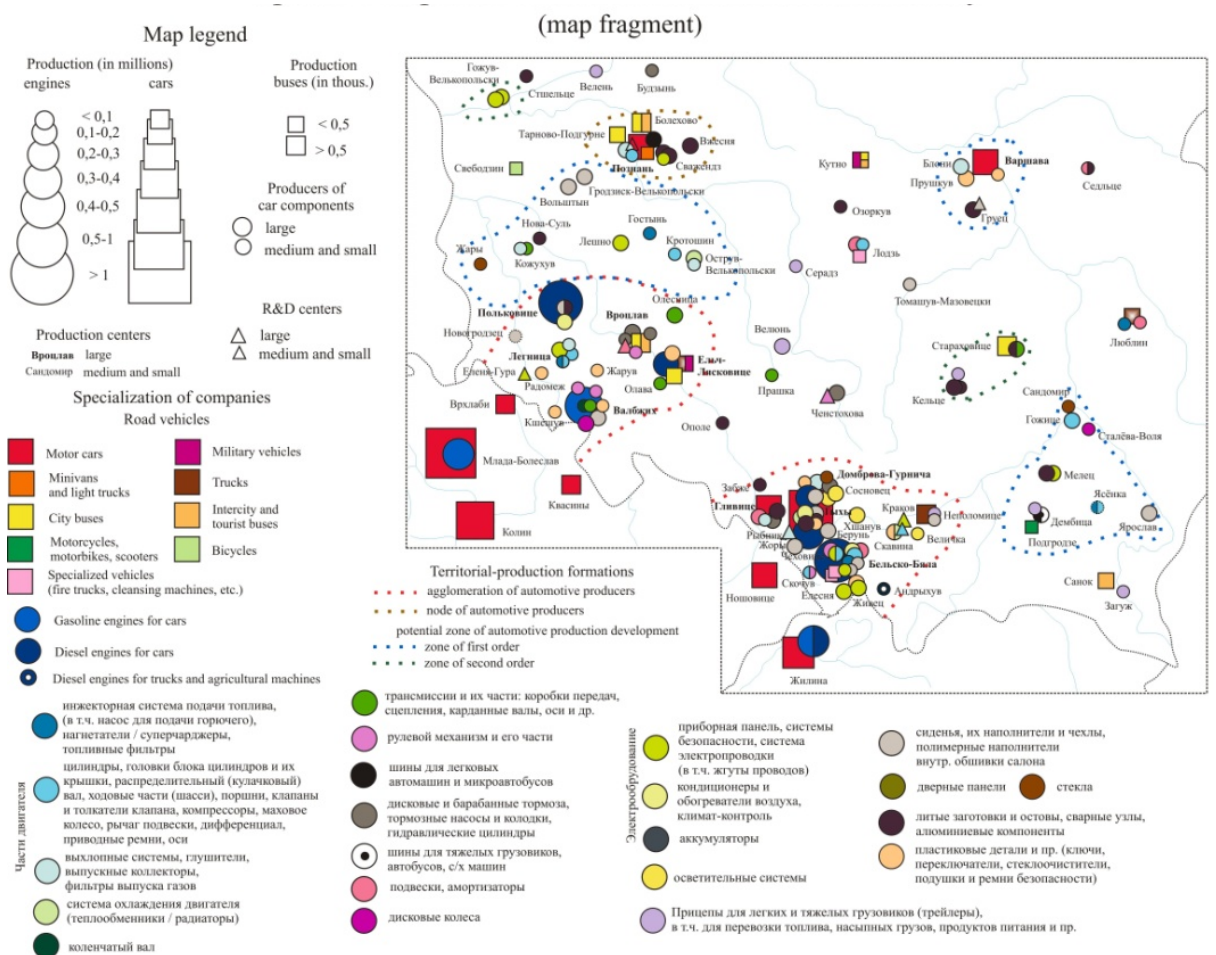

Figure 1 - Spatial complexes formation in automotive industry (Лобанов, 2010)

Numerous case studies indicate that an analysis of the sequence of self-organisation processes allows us to make an algorithm of actions for complex project implementation. Thus, the previously established methods of territorial-production complex formation (modelling or organisation from outside and self-organisation) are equal and mutually complementary. However, in our opinion, more attention should be paid to the complexes formed under the influence of market forces with minimal interference from external regulators. 


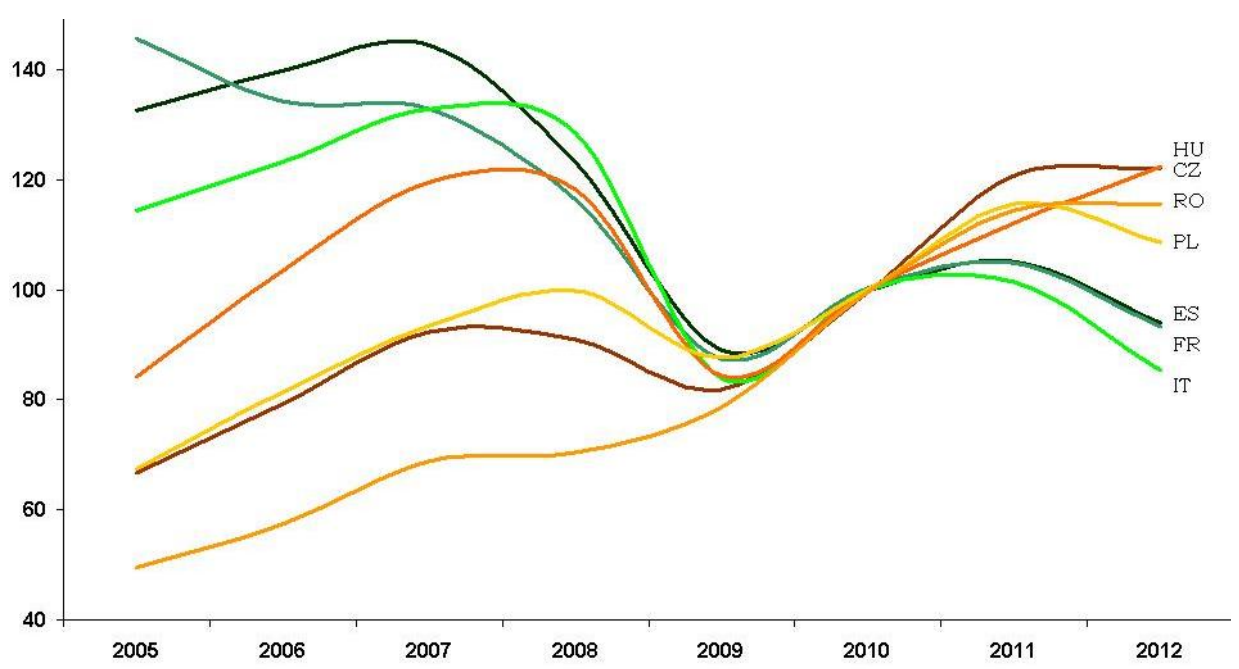

Figure $2 \mathrm{a}$ - Prospects of automotive industry development: CEE and SEE vs. Western and Southern Europe (Лобанов, 2010)

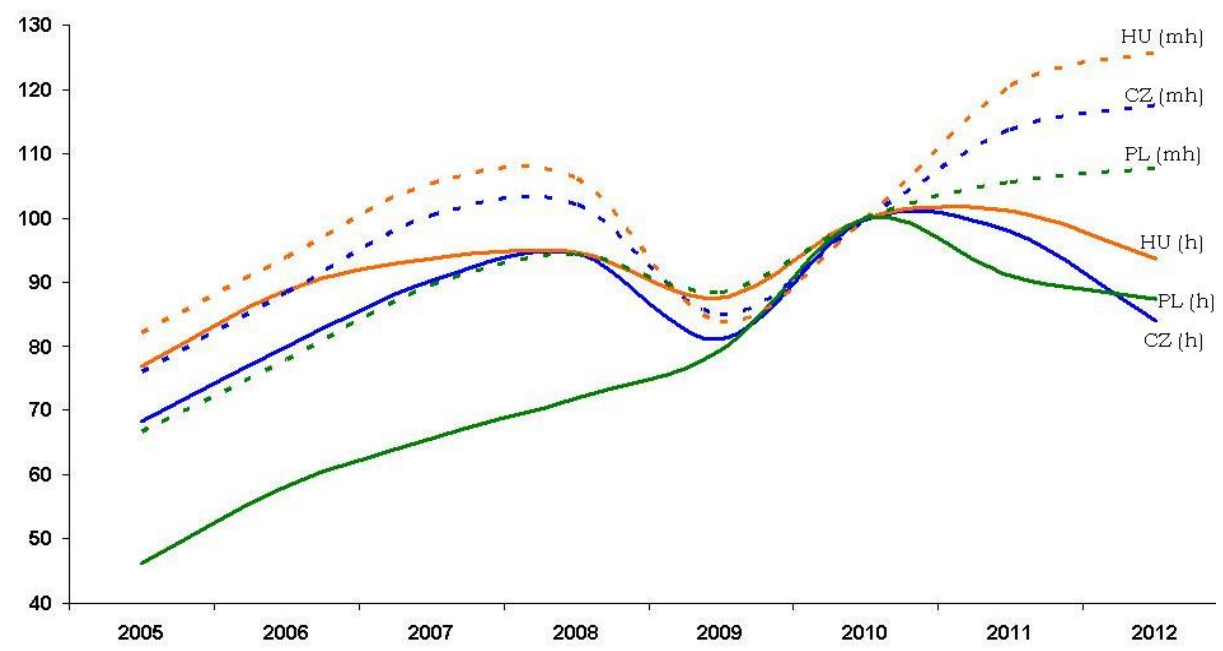

Figure $2 \mathrm{~b}$-Medium-high-tech industries (incl. automotive) seem less affected by crisis in comparison to hi-tech industries (Лобанов, 2010)

When performing an industrial zoning procedure, it is important to consider the features of spatial organisation such as areal, nodal or point form and the character of mutual relationships (complex or group). Among the latter, we distinguish the zones with the focal spread of industrial activities - the industrial areas of loosely linked and functionally dispersed businesses. Notably, the number of industrial groups is characterised by a high 
degree of industrial concentration. Territorial-production complexes are divided by the scale and their configuration: industrial regions and agglomerations (areal form), nodes (nodal form), centres and points (point form). Less complex formations may exist independently (autonomously), or they may be integrated into taxons of a higher order.

\section{Structures of industry in dynamics and their rationalisation and modernization}

The transformation of the functional and spatial structure can be represented as a continuous processor as the result of the structure development, fixing the state of its elements at some stage. According to our first definition, transformation is a continuous objective process, differentiated by the degree of intensity in time and space, which results in the metachronous, socio-economic development of the territory. The second explanation is more consistent with the goals and objectives of applied research, which is based on methods of system-structural analysis. Transformation as a specific result of structure development appears, therefore, as a display of the state of industrial complexes in transition from one point in time to another.

We call the time gaps between the structural transformations the stages of development (i.e., of industry, sector, subsector, and production). The period of the development of production systems is assigned to various rank orders that identify the time borders separating qualitative states of a given system. We investigated the evolution of industrial complexes in CEE countries beginning with the mid-twentieth century and singled out six completed stages of varying duration; the current conjuncture of the industrial markets can be described as the seventh development stage (Kulikova \& Lobanov, 2010; Lobanov, 2011b). Notably, the stages of higher order may include several sub-stages when the basic characteristics of the industrial complex are preserved (e.g., general downward trend), but there are differences in the dynamics of secondary indicators. In addition the duration of the stages has been reducing, and this fact can be regarded as yet another confirmation of the general acceleration of the socio-economic processes (e.g., the duration of Kondratiev-Berry waves, and Moore's law).

A multi-scale investigation of economic efficiency parameters shows the practical failure of comprehensive, general programs of the functional and territorial structures because the regulations of the mechanisms vary depending on the organisational level of the system. Indicators of production efficiency and financial stability of enterprises, such as labour productivity, the power availability index, the resource intensity index, and profitability, are the basis for the analysis of the industrial combinations formed by them. The key role belongs to the indicators of systemic integrity that confirm the functional connectivity of complex objects. The operational efficiency of the industrial 
facilities of the complex is largely determined by the level of mutual technological relevance and their receptivity to innovations.

The modernisation of the industrial structure can be represented by a process of completion with respect to the upper parts of the production chains, allowing the transition from partial to full production cycles. Private vertically integrated companies striving for greater operational efficiency and enhanced competitive advantage are interested in building a complete production cycle and, thus, indirectly help solve the nationwide problem of economic interrelation development. A state industrial policy should not be limited by the determination of strategic priorities but should provide support to private initiatives aimed at improving economic competitiveness.

\section{Specific features of the complexation process in different industrial branches (CEE countries example)}

The differentiation of placement factors and conditions causes the existence of a large number of possible organisational combinations that vary by size and specialisation. We will consider the features of the complexation process referencing as examples the leading and most dynamic industrial branches in CEE countries - electronics, home electrical appliances and automobiles (see Figure $2 \mathrm{a}$ and $2 \mathrm{~b}$ ).

The production of electronics and electrical appliances is among the most complex branches of engineering. The efficiency of their operation is highly dependent on the workforce qualifications and a number of specific factors, such as the development level of metal-processing and the market saturation in non-ferrous materials. Electrical products are generally characterised by high value, mass and transportability, which contribute to their involvement in trade operations. The process of complexation in these industries has the following characteristics:

- The development of the complexation process strengthens the position of electronics and electrical engineering companies in the national economies of CEE countries. In the 2000s (2000-2010), the share of these branches in the GDP and their employment numbers in some states was comparable to that of the recognised leaders of the European hi-tech sphere - Germany, Finland and Ireland. Hungary reported 9.1\% (GDP) and 5.8\% (employment); Slovakia reported 5.9\% (GDP) and 7.1\% (employment); the Czech Republic reported 5\% (GDP) and 5.5\% (employment).The international division of labour and intra-industry specialisation in electronics is more pronounced than it is for the manufacture of household electrical appliances. For example, Hungary and the Czech Republic specialise in the production of mobile phones; Poland and the Czech Republic specialize in computer manufacturing; Slova- 
kia and Hungary manufacture DVD-players; Hungary focuses on printed circuit boards and data storage systems; and Poland and Hungary manufacture energy-efficient lighting ${ }^{5}$.

- Large international companies involved in the process of cross-border production outsourcing play an active role in complexation. Competitive advantages of the Eastern European region have contributed to the inflow of foreign investment, which indicates the beginning of a new phase of externalisation - the transfer of tangible (productive assets) and intangible (technology, know-how) values to the emerging markets of post-socialist countries ${ }^{6}$. Some investors have made a revolutionary decision for new market expansion, that is, the bypassing of the Western European countries as some of the U.S. and Asian companies have located their first and, often only, European production sites in the $\mathrm{CEE}^{7}$.

Western European and American companies, according to our assumption, in the medium term will begin their expansion into south-eastern Europe, which will be comparable to the development of the Hungarian, Czech and Polish markets in the 1990s. In addition, to optimise the production, these companies will transfer facilities to south-eastern Europe not only from the home markets but also from the more economically advanced CEE countries (and by the end of this cycle, from south-eastern Europe to developing economies) ${ }^{8}$. In contrast, east Asian and southeast Asian corporations will seek to increase their presence in Europe by creating an extensive sales network with high market capacity in developed countries and by locating industrial sites in countries with low production costs. Thus, the Asian electronics companies appear to be equally active in the use of the industrial potential of the northern and southern groups of eastern European republics. However, the production outsourcing from CEE countries to other regions remains unlikely.

\footnotetext{
${ }^{5}$ It is significant that Hungary, which specialized during the 2000 s in mobile phone and printed circuit board production, is gradually losing its advantages in competitive activity for foreign investment in these branches.

${ }^{6}$ For instance, American company Whirlpool moved the production of washing machines from French Amiens to the Slovak town of Poprad; Finnish Nokia placed the mobile phones factory in Romanian Cluj-Napoca after closure of its plant in German Bochum.

${ }^{7}$ This refers to Korean LG and Japanese Sharp operations in Poland.

${ }^{8}$ As an example, the closure of the IBM plant in Szekesfehervar in 2002 and the transfer of computer hard disks production facilities to China, which resulted in the dismissal of nearly four thousand people, or the significant staff reduction in Hungarian electronics factories during the crisis in 2008-09 (by Philips in Szekesfehervar and Szombathely, Foxconn in Komarom). In the second half of the first decade of the 2000 s, a crisis period, some of the foreign companies started to fold their presence in eastern European markets so as to optimize operations (e.g., Philips, Dell and Sony sold their factories to logistically more flexible Asian electronic contract assemblers.
} 
An analysis of the regional electronic industry suggests the existence of several strategies for the development of markets by foreign companies. Among them, we should note at least two main strategies. The first is typical for most corporations from east and southeast Asia, offering active expansion into promising markets and deploying branch networks, such as Samsung, Panasonic, Foxconn, Flextronics in three or more countries of the region, resulting in a dissipation of capital. Another strategy for the development of the eastern European markets is the creation of supporting industrial research centres, thereby accumulating investments from parent companies such as Nokia and IBM in Hungary, Sony in Slovakia before 2010 and LG and Sharp in Poland.

- Electronic and electrical appliance enterprises form a network of supply and serve cooperatives, the important structural elements of the territorial-production complexes that specialise in various machinery production? .

- Machinery complexes formed by electronics enterprises (playing the role of core components) are largely involved in foreign trade relations. Strategies of functional and spatial organisation vary depending on the degree of capacity and development of the domestic market. Nevertheless, most of these complexes should be classified as extraterritorial formations.

a) The placement of export-oriented electronics producers in the border areas with a predominant concentration of free labour (e.g., in the western regions of Slovakia and in Hungarian Central Transdanubia region one tenth of the employed population work in the manufacturing sector in electronics). For example, the electronics industry in Hungary is characterised by the most compound spatial structure of all the CEE countries. Its main elements are the mono- and polycentric agglomerations and the large industrial nodes located mainly in the capital metropolitan area and the western part of the country ${ }^{10}$.

\footnotetext{
${ }^{9}$ For example, electronics and automotive manufacturers in the Czech Republic form the Laba (Labe) territorial- production complex (audio devices are assembled at Panasonic plant in Pardubice for car factory TPCA in Kolin).

${ }^{10} \mathrm{We}$ distinguish several existing and potential zones of complexation in Hungary, the composition of which are defined by the largest TNCs (e.g., Philips, Samsung, GE, Nokia, Flextronics, and Foxconn): 1) agglomeration of electronics companies in Budapest and its satellite towns, some of which are gradually becoming poles of industrial growth of smaller level; 2) diversified industrial nodes in Transdanubian Region (Dunantul), located in the area of Budapest economic impact; 3) separate centres of inner type close to Balaton lake and Tisa river region; 4) frontier (closeto-border) centres of northern, western and southern parts of Dunantul; 5) frontier centres of the Eastern Alfeld.
} 
b) When the remoteness of production centres from the borders is not a limiting factor of development, complexes are developed. The nature of the labour orientation of enterprises depends on the complexity of the manufacturing processes. Thus, the choice is between the development in urban agglomerations with a high educational potential of the workforce or in poor, urbanised territories with low employment levels ${ }^{11}$. The latter option results in other benefits and preferences (e.g., institutional and fiscal benefits). For example, the placement of electronics companies in Poland is characterised by high dispersion, causing the autonomous existence of mutually distant points with relatively equal productive capacity ${ }^{12}$.

- The producers of household electrical appliances (involved in the formation of value chains in machinery) in the process of selforganisation are also affected by agglomeration effects. Poland is the leading country in the CEE and SEE based on its number of electrical companies and their production capacity. The development of a given branch in Poland does not experience an increase in specialised main production centres; rather, Poland experiences the formation of diversified agglomerations that consist of both new and upgraded older plants ${ }^{13}$. The main competitive advantages of Poland in comparison with its neighbouring countries are lower production costs, traditional specialisation in electrical products, the availability of industrial infrastructure and skilled personnel and, finally, a large domestic market. It should be noted that the capacity of a national market is a much more important factor for the location of consumer electronics assembly plants in comparison to the companies that produce electronic components and other items of intermediate consumption.

\footnotetext{
${ }^{11}$ A new wave of industrialization has an impact not only on the system of settling or transport infrastructure, but it also transforms the traditional social order, especially in economically less developed and sparsely populated areas. Thus, town Mlawa north of Warsaw being one of the leading centres of Polish electronics sector is increasingly referred to be LG town (it's well-known for non-official name "Mlawa - LG Town").

${ }^{12}$ Leading electronics enterprises in Poland (e.g., LG, Daewoo, Sharp, Philips, GE, Flextronics, and Foxconn) involved in the formation of several territorial-formation complexes that include: 1) agglomeration of high-tech producers of TV set and telecommunication equipment in the northern part of Poland near the Lower Vistula; 2) complexes with a diversified production structure in Lodz and their satellite towns; 3) specialized complex (TV set assembly) in the vicinity of Wroclaw formed by greenfield production facilities.

${ }_{13}^{3}$ Multinational producers of household electrical appliances (e.g., Electrolux, Samsung, Whirlpool, and Indesit) control more than twenty assembling centres in Poland, some of which are involved in the formation of industrial agglomerations with centres in Lodz and Wroclaw.
} 
- An important characteristic of the spatial and functional organisation of machinery complexes is the formation of connections between original equipment manufacturers (OEM), that is, companies specialising in assembling and producing the final products from a variety of accessories supplied by outer firms. They act as brand owners, such as assembly plants in the automotive industry, or as subcontractors as in electronics and electrical engineering. Among the OEM component suppliers are contractors of different orders (first, second and third tier suppliers) who form a combination of horizontal and vertical linkages. As a rule, assembly companies located in European countries choose their traditional partners from previously developed markets (mostly from the country of origin) as their firstorder suppliers. As for local businesses, in most cases, they defer to suppliers at the second and third tiers.

Electronic production companies should be divided into two types based on their development strategy and the principles of industrial organisation. The first unites firms manufacturing products under their own brand while the second, the so-called contract assemblers, sign agreements with well-known trademark holders (electronic contract manufacturing, ECM) ${ }^{14}$. The key features of ECM are production and management flexibility, which allows them to respond quickly to changing market conditions such as switching to new products, increasing or decreasing the proportion of facilities involved, and participating actively in the purchase and sale of assets ${ }^{15}$.

- The effectiveness of complexation in the eastern European states, to a great extent, depends on the development of the social infrastructure of the economy. One of the key competitive advantages of the region is the educational potential of the population that contributes to the transfer in $\mathrm{CEE}$ of production facilities and their associated research institutions. In large cities and urban agglomerations (Budapest, Bucharest, Warsaw, Prague, Brno and others), multinational companies carry out R\&D with the most high-tech modern production such as the production of plasma panels, the development of new product modifications and the providing of services in the field of information technologies (see Figure 3).

One of the most important subsectors of engineering is the automotive industry, which comprises enterprises that assemble cars, trucks, buses, trolley

\footnotetext{
${ }^{14}$ Among the largest companies operating in the CEE countries by contract schemes are Flextronics (Singapore) and Foxconn (Taiwan). It is noteworthy that some local firms tend to adopt their experiences: for example, the Hungarian Videoton since the end of the 1990s provides various electronics producers with its manufacturing facilities.

${ }^{15}$ Assembly plants of ECM can completely change the specialization and organization profile, such as the Flextronics plant in Nyiregyhaza, which came under the control of the Danish toy manufacturer Lego in the late 2000s.
} 
buses, motorcycles and other wheeled vehicles. Among the main features of automotive manufacturing are the high degree of involvement by both production and non-production entities in the specialisation and cooperation processes, the complexity of business relations and technological cycles (e.g., assembly plants, complementary and related firms), and the active participation in the formation of territorial-production complexes and groupings (see Figure 1).

The characteristics of internal organisation complexation in the CEE automotive industry should be attributed to a separate type when the influence of large multinational companies on the manufacturing processes can be limited only by the final or, in rare cases, the intermediate stages. For example, the majority of the upper Silesian industrial and service companies involved in the production of passenger cars are not included in a vertically integrated holding company but are linked only by cooperation agreements. Car assemblers and producers of the most advanced car accessories are controlled by the leading transnational companies (TNCs), which are usually considered as traditional partners, for example, the partnerships and alliances between GM and Fiat or GM and Isuzu. Intermediate levels are represented by various car component producers forming specialised industrial agglomerations. Competing and cooperating companies of such agglomerations are established either simultaneously or after the construction of the assembly plants, as is the case in upper Silesia with the manufacturers of electrical equipment, lighting systems, seats, engine parts and metal items. Each of these production chain links should be considered in spatial aspect as territorialproduction formations of a cluster type. Suppliers relating to the initial links of the production chain also form horizontally integrated structures that are involved in the creation of core vertical linkages. We argue that the upper Silesian automotive agglomeration is characterised by a high level of integration with the Warsaw automotive node and certain Hungarian agglomerations. The process of intra-branch integration contributes to the development of functional relationships among the corresponding complexes, namely, Upper Silesian, Warsaw and Budapest industrial regions.

The above-mentioned examples show that vertically integrated corporations presented in the CEE do not form territorial-production complexes, as is usually assumed; rather, they are involved in the processes of complexation. The extent of their participation in the formation of complexes depends on the dominant model of economic activities in the given area and certain particular factors, such as the characteristics of technology cycles. 


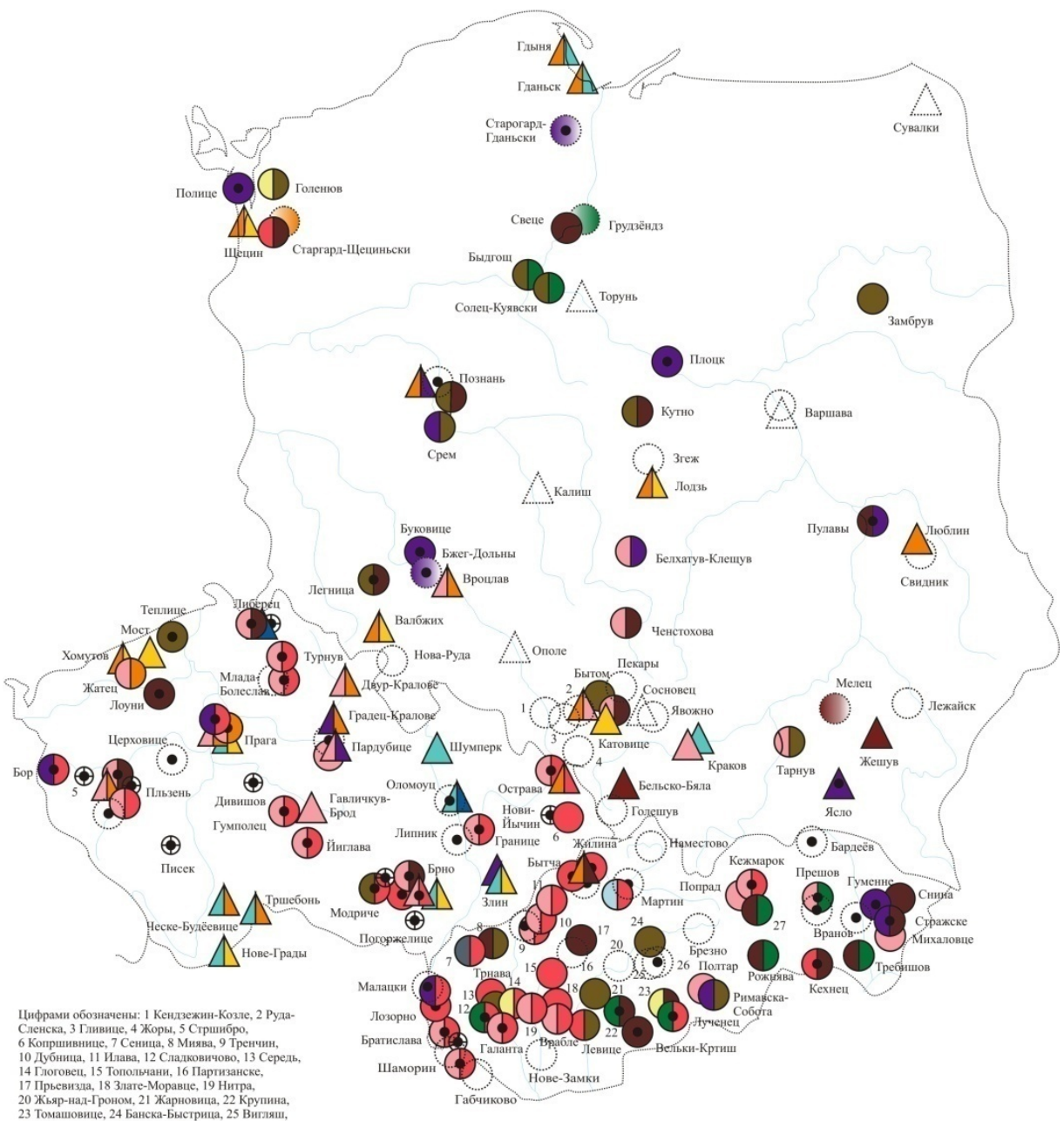

23 Томашовице, 24 Банска-Быстрица, 25 Вигляш,

Map legend

O

Industrial parks managed by municipal and regional authorities

\section{$\odot$}

legal entitities

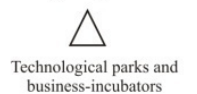

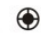

Main external logistical centers

Parks in different stages of formation established parks searching for first investors

$\begin{array}{ll}\text { Functional structure of parks } & \begin{array}{c}\text { Note: industrial zones } \\ \text { are not shown on the map }\end{array} \\ \text { Aircraft building complex } & \text { Wood-working, pulp\&paper, furniture production, etc } \\ \text { Electronics and electrical appliances } & \text { Food \& beverages } \\ \text { General machinery and metal-processing } & \text { Metal and plastic construction materials, package } \\ \text { Energy complex, incl. alternative energy technologies } & \text { Telecommunication, information technologies } \\ \text { Chemical industry, incl. lean chemicals } & \text { Biotechnology } \\ \text { Ferrous metallurgy } & \text { Nanotechnology }\end{array}$

Figure 3 -Industrial and technological parks in CEE countries (Лобанов, 2010) 


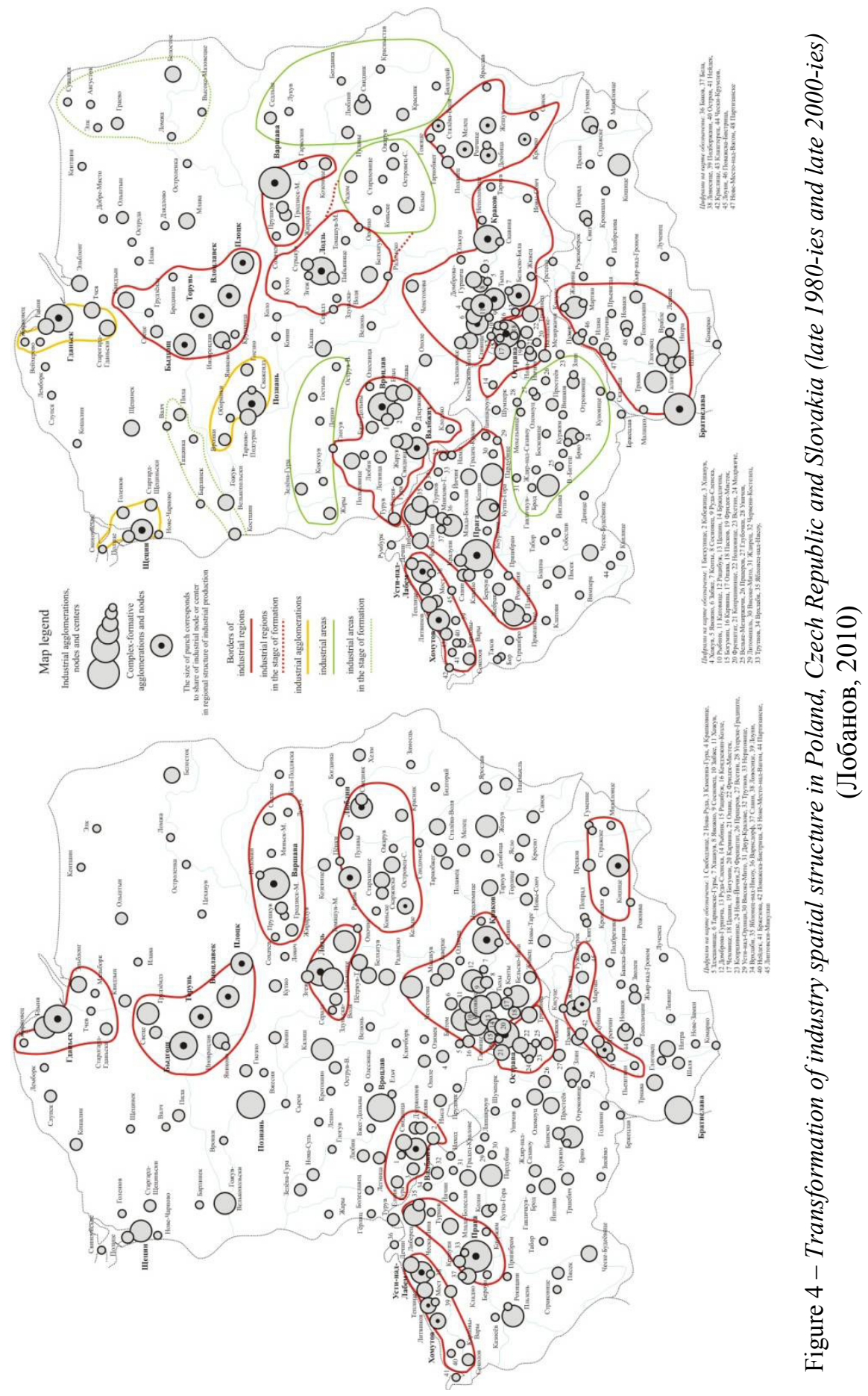




\section{Post-crisis transformation of spatial and functional structure of industry in CEE countries (medium-term prognosis)}

Crucial changes in the configuration of territorial-production formations in market conditions can be seen when comparing the maps of the territorial structure of the industry in the CEE at the end of the 1980s and 2000s. In the second half of the 1980s in the most industrialised northern part of the CEE, there were 12 industrial regions that specialised primarily in fuel, metallurgy or machinery. In the late 2000sin the given territory, we singled out 10 industrial regions and 3 industrial agglomerations, as well as a number of nodes and centres that are not involved in the larger formations. In addition, among the territorial-production groupings, we differentiated 6 industrial areas in various stages of formation. A decline in the number of the most complex systems is not evidenced in the development of the industry territorial structure. There are some new areas (e.g., Carpathian) and a number of previously developed areas characterised by the expansion of borders and the increasing complexity of internal organisations (especially central Bohemian, lower Silesian and eastern Slovakian industrial regions).

The functional (branch) macrostructure of most territorialproduction formations has not changed significantly; however, at the mesoand micro- levels, the diversification process with a simultaneous rotation of the functional combinations is typical. In the given countries, the highest degree of branch diversification refers to the capital industrial regions (e.g., Warsaw, Prague, Bratislava, and Budapest), as well as to those areas with a long history of industrialisation (e.g., the upper Silesian and MoravianSilesian). Their leading and/or specialised branches and sub-branches form complex systems whose products are competitive in both the domestic and foreign markets. For some industries, such as the traditional industries of the mining sector (coal, oil and gas), manufacturing industries requiring resources (heavy machinery) and labour-intensive industries (textiles and clothing) the manufacturing processes have ceased to be among the most efficient. The reasons for the low efficiency of manufacturing industries, which limits their potential competitiveness, can be reduced to investment deficits and technological gaps. In the medium term, high entrepreneurial activity will be observed in electronics and electrical engineering, transport and high-precision engineering, alternative energy, the chemical industry based on organic synthesis, metal-processing, secondary metallurgy, food and beverage production, construction and packaging materials production. In the industrial areas and other categorizations, a main trend of functional structure evolution is the development of food-processing, woodworking, some engineering and metal-processing industries (primarily, automotive, electronics and electrical engineering). We analysed the complex-formative 
and the specialised branches of territorial-production combinations in CEE countries, as well as branches with favorable and unfavorable development prospects (Table 1 and 2).

An important feature of the transformation processes in industries of the CEE is the evolution of location factors. Industrial agglomeration reduces the level of variable costs, but its contribution to the efficiency of enterprises of the complex becomes less significant; that is, the importance of geographical proximity weakens the conditions of expansion of intangible flows between economic entities. However, the widespread development of information channels and the desire to create equal conditions for access to them, in effect, encourages a return to traditional competition factors. The current orientation of companies (e.g., transport, labour, and sources) causes both centrifugal and centripetal tendencies in their placement, that is, the shift to economic centres with the best combination of production factors and, to the same extent, the development of some border areas. Improvement of transport infrastructure contributes to spatial shrinking and, as a result, to material resource maintenance and to time saving. Thus, in CEE countries, the phenomenon of main lines of transport development is of significant importance. For example, new enterprises are characterised by the orientation of highways connecting major industrial centres of Warsaw and Lodz, Prague and Plzen, Mlada Boleslav and Liberec, and Brno and Jihlava. Changes in the sectoral structure of employment, labour mobility and technological modernisation negate the dependence of some industries on manpower concentration, but professional skills are still a significant limiting factor with respect to placement decisions and procedures.

The territorial composition of industrial entities is subject to significant change, as shown on our maps. It is not only about the dynamics of production capacities of individual nodes or centres but also about the change of their roles within the larger territorial-production formations. Mono-centric complexes presented by industrial agglomerations and capital industrial regions dominate the CEE whereas bi-centric complexes, in contrast, are not typical for given countries (the exception is the lower Silesian region with two major nodes - Wroclaw and Walbrzych). In the 1990, and 2000s some poly-centric complexes moved into the category of bi-centric (for example, western Czech Republic) or were included in the new territorial-production formations (for example, the Povazie region joined western Slovakia greater region). It is noteworthy that modern poly-centric complexes are comprised of 4 or 5 equivalent centres, as in the sub-Carpathia and Kuyavia regions. We predict that in the medium term the number of such complexes will be reduced while the likelihood of the creation of mono-centric and, to a lesser extent, bi-centric complexes will remain high. The urban structure of industrial production in the CEE has also changed, 
despite the persistence of the correlation between population size of settlements and their total production potential. In the largest cities, the share of the industry in the economy continues to decline. As a result, the city of the second order, in terms of the preservation of their industrial specialisation, may claim a leading position in the distribution of production facilities. The inflow of foreign capital leads to the involvement of small- and mediumsized settlements in the spatial structure of industry, even in those areas with initially under-developed production infrastructure (see Figure 1).

Table 1 - Branch structure of territorial-production formations in Poland, the Czech Republic and Slovakia

\begin{tabular}{|c|c|c|}
\hline \multicolumn{3}{|c|}{ Territorial-production complexes } \\
\hline \multicolumn{3}{|c|}{ Industrial regions and agglomerations } \\
\hline \multicolumn{2}{|c|}{$\begin{array}{l}\text { Name of territorial-production } \\
\text { formation }\end{array}$} & $\begin{array}{l}\text { Prospective (promising) branches and sub-branches with } \\
\text { the most favorable investment conditions }\end{array}$ \\
\hline $\begin{array}{c}\text { Eastern Pomorze / } \\
\text { Pomerania (Kashubia) }\end{array}$ & A & $\begin{array}{c}\text { Alternative energy, electronics, organic chemicals, car } \\
\text { components }\end{array}$ \\
\hline $\begin{array}{c}\text { Western Pomorze / } \\
\text { Pomerania (Lower Odra) }\end{array}$ & A & $\begin{array}{l}\text { Alternative energy, organic and inorganic chemicals, car } \\
\text { components, electronics }\end{array}$ \\
\hline Kuyavia and Vistula & $\mathrm{R}$ & $\begin{array}{c}\text { Organic and inorganic chemicals, packaging materials, } \\
\text { electronics }\end{array}$ \\
\hline Warsaw & $\mathrm{R}$ & $\begin{array}{c}\text { Food and beverages, electronics and electrical appliances, } \\
\text { lean chemicals, construction materials }\end{array}$ \\
\hline Sub-Carpathia & $\mathrm{R}$ & $\begin{array}{c}\text { Automotive and aircraft building, inorganic and organic } \\
\text { chemicals, metal-processing }\end{array}$ \\
\hline Lodz & $\mathrm{R}$ & $\begin{array}{c}\text { Electrical appliances and electronics, construction } \\
\text { materials, chemicals }\end{array}$ \\
\hline Poznan & A & Automotive, food and beverages \\
\hline Lower Silesia & $\mathrm{R}$ & $\begin{array}{c}\text { Automotive, electrical appliances and electronics, } \\
\text { metal-processing }\end{array}$ \\
\hline Upper Silesia & $\mathrm{R}$ & $\begin{array}{l}\text { Automotive, electronics and electrical appliances, secondary } \\
\text { ferrous metallurgy, non-ferrous metallurgy, metal-processing, } \\
\text { electricity generation, food and beverages }\end{array}$ \\
\hline $\begin{array}{l}\text { Western Czech } \\
\text { (Krusnehory) }\end{array}$ & $\mathrm{R}$ & Chemicals, alternative energy, construction materials \\
\hline Central Czech (Prague) & $\mathrm{R}$ & $\begin{array}{l}\text { Car components, high-tech industries, equipment and } \\
\text { instruments, electronics and electrical appliances, food, } \\
\text { secondary non-ferrous metallurgy, metal- processing, } \\
\text { packaging made of plastic, paper and light metals }\end{array}$ \\
\hline Moravian-Silesian & $\mathrm{R}$ & $\begin{array}{l}\text { Metal-processing, high-tech industries (incl. alternative } \\
\text { energy), transport machinery and electronics }\end{array}$ \\
\hline Western Slovakia & $\mathrm{R}$ & $\begin{array}{l}\text { Car components, inorganic and organic chemicals, food } \\
\text { and beverages, electronics and electrical appliances }\end{array}$ \\
\hline
\end{tabular}

Comment: $\mathrm{R}$ - industrial region, $\mathrm{A}$ - industrial agglomeration; 
Industrial activity in CEE countries: post-crisis transformation of spatial and...

Table 2 - Groupings of production entities, including groupings forming industrial areas in Poland, the Czech Republic and Slovakia

\begin{tabular}{|c|c|c|c|}
\hline \multicolumn{3}{|c|}{$\begin{array}{l}\text { Name of territorial-production for- } \\
\text { mation }\end{array}$} & $\begin{array}{l}\text { Prospective (promising) branches and sub-branches } \\
\text { with the most favorable investment conditions }\end{array}$ \\
\hline \multicolumn{2}{|c|}{ Pomorze / Pomerania } & G & Alternative energy, electronics, wood-processing \\
\hline \multicolumn{2}{|c|}{ Warmia and WestMasuria } & G & Food products, agricultural machinery \\
\hline \multicolumn{2}{|c|}{ Masuria and Podlasie } & FA & Food products, agricultural machinery \\
\hline \multicolumn{2}{|c|}{$\begin{array}{l}\text { Lublin / Lubelskie } \\
\text { and Podlasie }\end{array}$} & A & Food products and beverages \\
\hline \multicolumn{2}{|c|}{$\begin{array}{l}\text { Swietokrzyskie } \\
\text { (Radom-Kielce) }\end{array}$} & A & $\begin{array}{l}\text { Construction materials, food and beverages, } \\
\text { wood-processing }\end{array}$ \\
\hline \multicolumn{2}{|c|}{ Gorzow-Pila } & FA & Electronics, paper and paperboard \\
\hline \multicolumn{2}{|c|}{ Lubusz } & A & Gas-processing, car components \\
\hline \multicolumn{2}{|c|}{ Sumava and Southern Czech } & G & $\begin{array}{c}\text { Food products, high-tech industries (incl. alternative } \\
\text { energy), wood-processing }\end{array}$ \\
\hline \multirow{3}{*}{$\begin{array}{l}\text { Moravia, Hana } \\
\text { and Vysocina }\end{array}$} & Moravia & \multirow{3}{*}{ A } & $\begin{array}{l}\text { Precision engineering (equipment for vehicles, power } \\
\text { machinery, general machinery), aircraft building, } \\
\text { plastic products }\end{array}$ \\
\hline & Hana & & High-tech industries (incl. machinery) \\
\hline & Vysocina & & $\begin{array}{l}\text { Precision engineering (robotics and instrumentation), } \\
\text { food products, wood-processing }\end{array}$ \\
\hline \multicolumn{2}{|c|}{ Eastern Slovakia } & G & $\begin{array}{l}\text { Metal-processing, organic chemicals, electronics and } \\
\text { electrical appliances }\end{array}$ \\
\hline
\end{tabular}

Comment: $\mathrm{G}$ - elementary grouping of industrial entities, A - industrial area, FA - industrial area in the formative stage.

Borders of territorial-production formations are obviously inconstant; thus, up-to-date configurations represent the features of mutual location and interaction only during a specific period of time. The expansion of boundaries is accompanied by increased territorial contiguity. For example, the Warsaw industrial region played an important role on the socialist stage with respect to the orientation towards transport routes linking Poland and the republics of the USSR. Under new market conditions, regional enterprises substantially limited their reliance on contractors from the CIS countries and focused on meeting domestic demands. The integration of business activities on border territories are in the past as they were replaced by functionally weakly-related industrial areas. The eastern borders of CEE and SEE countries almost fail to fulfill their contact functions to stimulate cross-border production, which is typical of Masuria and sub-Carpathia in Poland, the eastern parts of Hungary and Slovakia, and the northern part of Romania. On the contrary, the involvement of eastern European enterprises in foreign economic relations contributes to the industrial activity along the western borders and increases the probability of the establishment of first cross-border complexes 
(see figure 4). For example, the internal organisation of the upper Silesian and Moravian-Silesian, as well as the lower Silesian and central Czech Republic industrial regions, allows us to treat them as unified territorialproduction formations. Prospects for unification depend not only on the operational transparency of enterprises and mobility of production factors but also on the rate of integration development, in general.

There are many factors that contribute to the problems of industrial production efficiency. Of particular significance, is the lack of correspondence between the supply and demand of long-term capital, skilled labour, and technology. The high degree of dependence on the external economic situation bears certain structural risks, especially when considering the existing disparity in the level of productivity of domestic and foreign companies. The export-oriented model of industrial development in countries with a small national market capacity has several advantages at the stage of growth; however, in terms of the spread of crisis, its use leads to macroeconomic instability. The outflow of capital and the slowdown of its inflow during the 2008-2009 economic crisis reflects more than just the vulnerability of this model for CEE countries. The given trend reflects the need to incorporate TNCs subsidiaries in the value chains of home companies, thus limiting the scope of production transfer abroad in the near future. An additional problem is that the import of capital is not accompanied by the adaptation of modern technologies and enhanced knowledge while the domestic R\&D is being poorly commercialised. To enhance the role of high-tech industries, which remain insignificantly represented in complexation processes, one should maintain closer cooperative links, based on regional educational and research potential, between the objects of the production infrastructure. State industrial policies, furthermore, should not be limited to the definition of strategic priorities and objectives of structural rationalisation but also provide support to private initiatives aimed at improving national competitiveness.

\section{Acknowledgments}

This article is dedicated to the memory of Professor E. B. Valev.

\section{References}

Лобанов М.М. (2009). Теория и практика размещения промышленного производства. Сборник докладов участников Первого Российского экономического конгресса. Москва: Институт экономики РАН.

Лобанов М.М. (2010). Теоретические и практические проблемы организаџии промышиенного производства в современных условиях развития мирового 
хозяйства. Москва: Институт экономики РАН. Retrieved from: http://inecon.org/images/stories/institut/zasedaniya-uchenogo-

soveta/Lobanov.pdf (text), http://inecon.org/images/stories/institut/zasedaniyauchenogo-soveta/Lobanov_1.pdf,

http://inecon.org/images/stories/institut/zasedaniya-uchenogosoveta/Lobanov_2.pdf.

Лобанов M.M. (2011a). Формирование комплексов и кластеров в промышленности в условиях рыночных отношений. Журнал Новой экономической ассоцчиации, 10.

Лобанов М.М (2011b). Тенденции промышленного комплексообразования в современных условиях. Сборник научных трудов памяти Н.В.Алисова «Глобальная сочиильно-экономическая география». Москва-Смоленск: Ойкумена.

Лобанов, М.М. (2013). Структурная модернизация промышленности. Модернизация в странах российского пояса соседства: структурный и технологический аспекты. СПб.: Нестор-История.

Audretsch, B. (1998). Agglomeration and the location of innovative activity. Oxford Review of Economic Policy, 14 (2), 18-29.

Buturac, G., Lobanov, M. (2011). The influence of economic structure transformation on mutual trade: Russia and South-Eastern European countries. In: Materials of SEE Management forum (153-178). Zagreb.

Coe, N., Hess, M., Wai-chung Yeung, H., Dicken, P., \& Henderson, J. (2004). 'Globalizing' regional development: a global production networks perspective. Transactions of the Institute of British Geographers, 29 (4), 468-484.

Enright, M. J. (1993). The geographical scope of competitive advantage. Changing scales for regional identity. Utrecht.

Iammarino, S., \& McCann, P. (2006). The structure and evolution of industrial clusters: Transactions, technology and knowledge spillovers. Research Policy, 35 (7), 1018-1036.

Kulikova, N., \& Lobanov, M. (2010). The role of FDI in the economic modernization of Central and Eastern European EU member states. Development potentials of foreign direct investment (165-179). Belgrade: IIPE.

Scott, A. J., \& Storper, M. (2009). Rethinking human capital, creativity and urban growth. Journal of Economic Geography, 9, 147-167.

Sölvell, Ö., Lindqvist, G., \& Ketels, C. (2003). The Cluster Initiative Greenbook. Stockholm: The Competitiveness Institute.

Szanyi, M., Csizmadia, P., Iwasaki, I., and others (2010). The relationship between supplier networks and industrial clusters: an analysis based on the cluster mapping method. Eastern Journal of European Studies, 1, 87-112. 
Оригинални научни рад

Михаил М. Лобанов

\section{ИНДУСТРИЈСКА ДЕЛАТНОСТ У ЗЕМЉАМА ЦЕНТРАЛНЕ И ИСТОЧНЕ ЕВРОПЕ: ПОСТКРИЗНА ТРАНСФОРМАЦИЈА ПРОСТОРНЕ И ФУНКЦИОНАЛНЕ СТРУКТУРЕ}

\section{Резиме}

У раду се проучава индустријски развој у земљама Централне и Источне Европе са фокусом на еволуцију просторне и функционалне структуре индустрије. На примеру развојних услова пре и после кризе, аутор издваја заједничке и посебне карактеристике структурних трансформација у индустрији на националном и регионалном нивоу. Потребно је поменути да померања структуре индустрије су истражени на основу промена у територијалнопроизводним формацијама. Аутор открива специфичности процеса индустријског комплексирања и разликује моделирање и самоорганизовање ових формација. Типологија територијално-производних формација која користи критеријуме њиховог састава и фазу еволуције је такође предложена. Постоје различите методе научних истраживања које се користе у раду укључујући метод мапирања којим се потврђују резултате анализе података. Треба нагласити да рад садржи прогнозу развоја просторне и функционалне структуре индустрије у земљама Централне и Источне Европе. 